\title{
Community structure of metazoan parasites in Hemibrycon surinamensis (Characidae) from the Matapi River in the State of Amapá, Brazil
}

\author{
BRIANI O. SOUSA ${ }^{1}$, MARCOS S.B. OLIVEIRA ${ }^{2}$ and MARCOS TAVARES-DIAS ${ }^{3}$ \\ ${ }^{1}$ Graduação em Biologia, Universidade Federal do Amapá/UNIFAP, Rodovia \\ Juscelino Kubitschek, s/n, 68903-419 Macapá, AP, Brazil \\ ${ }^{2}$ Programa de Pós-Graduação em Biodiversidade Tropical, Universidade Federal do Amapá/ \\ UNIFAP, Rodovia Juscelino Kubitschek, s/n, 68903-419 Macapá, AP, Brazil \\ ${ }^{3}$ Embrapa Amapá, Rodovia Juscelino Kubitschek, 2600, 68903-419 Macapá, AP, Brazil \\ Manuscript received on April 23, 2018; accepted for publication on September 13, 2018
}

\begin{abstract}
How to cite: SOUSA BO, OLIVEIRA MSB AND TAVARES-DIAS M. 2019. Community structure of metazoan parasites in Hemibrycon surinamensis (Characidae) from the Matapi River in the State of Amapá, Brazil. An Acad Bras Cienc 91: e20180393. DOI 10.1590/0001-3765201920180393.

Abstract: The aim of this study was to investigate the community of metazoan parasites in Hemibrycon surinamensis from the Matapi River, State of Amapá, Brazil. Among the 31 examined fish, $77.4 \%$ were parasitized by Jainus hexops, Tereancistrum ornatus (Monogenea), Contracaecum sp. (Nematoda), Clinostomus marginatum and Posthodiplostomum sp. (Digenea). However, the dominance was of monogeneans $J$. hexops and T. ornatus, and among the endoparasites, the predominance was of species at the larval stage. The parasites showed random dispersion. Brillouin diversity index varied from 0 to 0.9 , evenness from 0 to 0.7 and species richness from 0 to 3 parasites per host. Low levels of parasitic infection were observed and discussed. The results indicate that this intermediate host occupies a low position in the food web. This is the third eco-epidemiological study for H. surinamensis.
\end{abstract}

Key words: ectoparasites, freshwater fish, diversity, monogeneans.

\section{INTRODUCTION}

Hemibrycon surinamensis Géry, 1962 is a Characidae fish with distribution only in South America - in the basins of French Guiana, Suriname and basins of Amazon, Tapajós, Tocantins and Xingu rivers, Brazil. This benthopelagic fish have omnivorous habit whose diet is yet little known, but it can feed on microcrustaceans and mollusks (Hoshino et al. 2014, Froese and Pauly 2019). Small size fish, males reach maximum length of 8.0

Correspondence to: Marcos Tavares-Dias

E-mail: marcos.tavares@embrapa.br

ORCid: https://orcid.org/0000-0002-8376-1846 $\mathrm{cm}$ and females $9.1 \mathrm{~cm}$ (Froese and Pauly 2019). In some regions of the Amazon, this species is marketed as ornamental fish (Prang 2007), but not in eastern Amazon.

The Matapi River, a left bank tributary of the Amazon River, is born in the central region of the State of Amapá, in the Northwest-Southeast direction, and flows into the Amazonian estuary, near the city of Santana, but establishes limit with three municipalities of this state. Thus, daily the Matapi River basin is flooded by the daily tides of the Amazon River, because its geomorphology is characterized by the coastal plain of the southern Amapá (Takyiama et al. 2007, Silva et al. 2016). 
For H. surinamensis from Igarapé Fortaleza basin, infection by Ichthyophthirius multifilis, Piscinoodinium pillulare, Jainus hexops, Tereancistrum sp., Ergasilus turucuyus, Argulus sp., Derogenidae gen. sp., Genarchella genarchella, Cucullanus sp. and Contracaecum sp. was reported by Hoshino et al. (2014). The transmission of ectoparasites is influenced mainly by the behavior of the host fishes, which facilitates that these parasites find their hosts by active dispersion. Helminth endoparasites can be used to provide information on trophic interactions, since they have a complex life cycle, which requires several hosts at different trophic levels, and their transmission is dependent on the predator-prey relationship (Cloutman 1975, Takemoto et al. 2013, Hoshino et al. 2014, Oliveira et al. 2017, Baia et al. 2018). Therefore, as there is little information on parasites of $H$. surinamensis, this study investigated the community of metazoan parasites of this host from the Matapi River, in the State of Amapá, Brazil.

\section{MATERIALS AND METHODS}

FISH AND COLLECTION AREA

In October 2017, 31 specimens of $H$. surinamensis $(7.3 \pm 0.7 \mathrm{~cm}$ and $13.5 \pm 4.8 \mathrm{~g})$ were collected in the Matapi River, near the municipality of Santana, State of Amapá, Brazil (Figure 1), for parasitological analysis. Fish were caught using $10 \mathrm{~mm}$ mesh between opposite knots. Fish were transported packed in ice to the Aquaculture and Fishery Laboratory from Embrapa Amapá, Macapá (AP).

This study was conducted in accordance with the principles adopted by the Brazilian College of Animal Experimentation (COBEA) and approved by the Ethics Committee on the Use of Animals (CEUA/CPAFAP: 011/2018).

\section{COLLECTION PROCEDURES AND PARASITES} ANALYSIS

All fish were weighed (g) and measured for total length $(\mathrm{cm})$, and then necropsied for parasitological analysis. Each specimen's mouth, opercula, gills and gastrointestinal tract were examined to collect parasites (protozoans and metazoans). Gills were removed, fixed in formalin (5\%) and analyzed under a microscope. To quantify metazoan parasites, each viscera was dissected separately on Petri dish and was examined with a stereomicroscope. Previously described techniques were used to collect, fix, conserve, count and stain the parasites for identification (Eiras et al. 2006). Parasites identification followed the recommendations of Moravec (1998) and Thatcher (2006).

To analyze the parasite infracommunities, the ecological terms used were those recommended by Bush et al. (1997). The following descriptors for the parasite community were calculated: the species richness, the Brillouin diversity index $(H B)$, evenness $(E)$ in association with diversity index, and dominance frequency (percentage of the infracommunities in which a parasite species is numerically dominant) (Rohde et al. 1995, Magurran 2004), using the Diversity software (Pisces Conservation Ltd., UK). The varianceto-mean ratio (ID) and the Poulin's discrepancy index (D) were calculated using the Quantitative Parasitology 3.0 software to detect the distribution pattern of the parasite infracommunity (Rózsa et al. 2000) for species with prevalence $>10 \%$. The ID significance for each infracommunity was tested using the $d$-statistics (Ludwig and Reynolds 1988).

\section{RESULTS}

In 31 specimens of $H$. surinamensis, a total de 56 parasites were collected such as Jainus hexops Kritsky \& Leiby, 1972; Tereancistrum ornatus Kritsky, Thatcher \& Kayton, 1980 (Monogenea); Contracaecum sp. (Nematoda); 


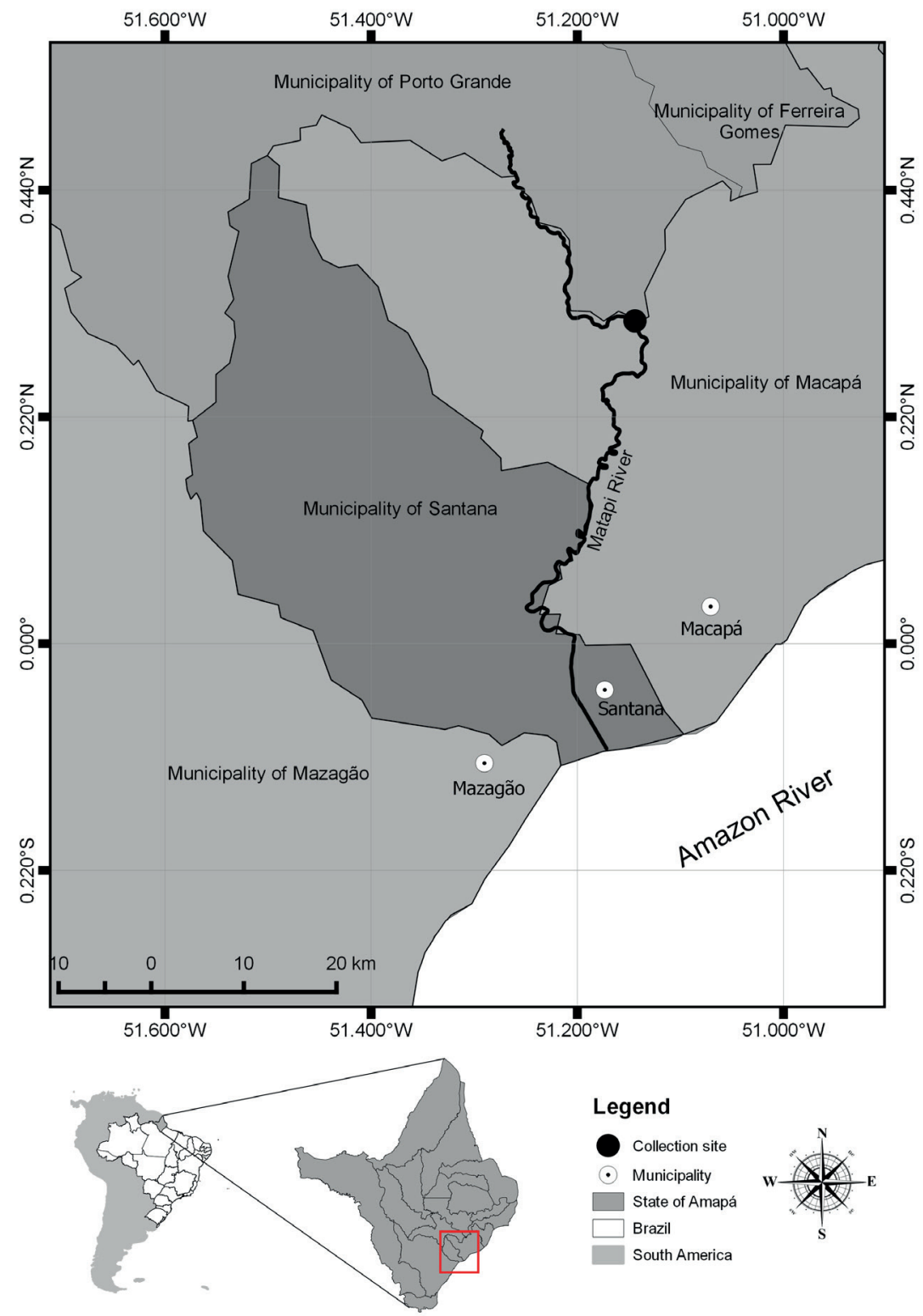

Figure 1- Collection site of Hemibrycon surinamensis in the Matapi River, Amapá State, Brazil.

Clinostomus marginatum Rudolphi, 1819 and Posthodiplostomum sp. (Digenea). However, the dominance was of monogeneans (Table I). The parasites presented random dispersion (Table II).

Of the analyzed fish, 77.4\% had at least one species of endoparasites or ectoparasites, and all endoparasites were found at the larval stage (Table III).

Brillouin diversity index ranged from 0 to 0.9 , evenness from 0 to 0.7 and species richness from 0 to 3 parasites per host (Table IV). There was a predominance of hosts with 0 to 2 parasites (Figure 2).

\section{DISCUSSION}

Since most wild fish can harbor several species of parasites, all community of parasites in a host population should be considered to adequately reflect the parasite-hostrelationship. The community of metazoan parasites in $H$. surinamensis from 


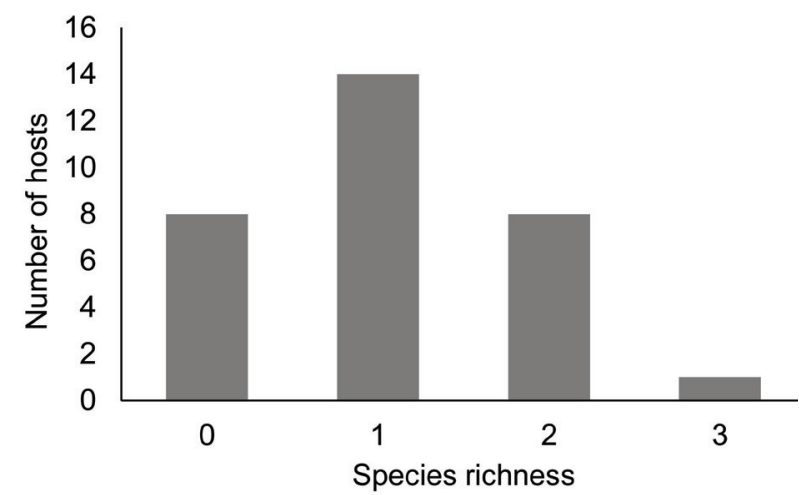

Figure 2 - Species richness of metazoan parasites in Hemibrycon surinamensis from the Matapi River, in Amapá State, Brazil.

the Matapi River was constituted by 2 species of Monogenea, 1 Nematoda and 2 Digenea. In contrast, for this same host from the Igarapé Fortaleza basin, it was reported 2 species of Monogenea, 2 Digenea, 2 Nematoda and 2 Crustacea, with high richness and diversity of species (Hoshino et al. 2014). In addition, the parasites of this study showed random dispersion, while Hoshino et al. (2014) found overdispersion pattern of parasites for this same host. Such differences can be attributed to factors that influence the diversity and richness of parasites, including environment, age, size and feeding of the hosts (Cloutman 1975, Madi and Silva 2005, Hoshino et al. 2014, Oliveira et al. 2017, Baia et al. 2018).

Several biotic and abiotic factors can influence the parasitism levels by monogeneans in wild fish, mainly the behavior of the hosts and the conditions of the environment. Sedentary fish or those living in lentic environments tend to be more exposed to these direct cycle parasites. However, other factors such as the length, sex and age of the hosts can also exert influence on the levels of parasitism (Cloutman 1975, Takemoto et al. 2013, Oliveira et al. 2017, Baia et al. 2018). In gills of H. surinamensis, it was found $J$. hexops, a monogenean originally described in Astyanax fasciatus from Costa Rica (Kritsky et al. 1972), and also T. ornatus, a monogenean originally described in Prochilodus reticulatus from Colombia (Kritsky et al. 1980). Recently, $T$. ornatus was reported parasitizing Moenkhausia sanctaefilomenae (Cohen et al. 2013). In $H$. Surinamensis, infection levels by $J$. hexops and $T$.

TABLE I

Metazoan parasites of Hemibrycon surinamensis from the Matapi River, in Amapá State, Brazil. P: Prevalence, MI: Mean intensity, MA: Mean abundance, FD: Frequence of dominance, TNP: Total number of parasites, SI: Site of infection, SD: Standard deviation.

\begin{tabular}{|c|c|c|c|c|c|c|c|}
\hline Species of parasites & $\mathbf{P}(\%)$ & $\mathbf{M I} \pm \mathbf{S D}$ & $\mathbf{M A} \pm$ SD & FD (\%) & Range & TNP & SI \\
\hline $\begin{array}{l}\text { Jainus hexops and } \\
\text { Tereancistrum ornatus }\end{array}$ & 60.0 & $2.0 \pm 1.4$ & $1.2 \pm 1.5$ & 0.64 & $1-5$ & 36 & Gills \\
\hline Contracaecum sp. (larvae) & 22.6 & $1.3 \pm 0.5$ & $0.3 \pm 0.6$ & 0.16 & $1-2$ & 9 & Intestine \\
\hline Contracaecum sp. (larvae) & 3.2 & $1.0 \pm 0$ & $0.03 \pm 0.2$ & 0.02 & - & 1 & Stomach \\
\hline Contracaecum sp. (larvae) & 3.2 & $1.0 \pm 0$ & $0.03 \pm 0.2$ & 0.02 & - & 1 & $\begin{array}{l}\text { Pyloric } \\
\text { cecum }\end{array}$ \\
\hline $\begin{array}{l}\text { Clinostomus marginatum } \\
\text { (metacercariae) }\end{array}$ & 3.2 & $1.0 \pm 0$ & $0.03 \pm 0.2$ & 0.02 & - & 1 & Gills \\
\hline $\begin{array}{l}\text { Clinostomus marginatum } \\
\text { (metacercariae) }\end{array}$ & 12.9 & $1.3 \pm 0.5$ & $0.2 \pm 0.5$ & 0.09 & $1-2$ & 5 & Tegument \\
\hline $\begin{array}{l}\text { Posthodiplostomum sp. } \\
\text { (metacercariae) }\end{array}$ & 3.2 & $1.0 \pm 0$ & $0.03 \pm 0.2$ & 0.02 & - & 1 & Intestine \\
\hline $\begin{array}{l}\text { Posthodiplostomum sp. } \\
\text { (metacercariae) }\end{array}$ & 3.2 & $2.0 \pm 0$ & $0.06 \pm 0.4$ & 0.04 & - & 2 & $\begin{array}{l}\text { Swim } \\
\text { bladder }\end{array}$ \\
\hline
\end{tabular}


TABLE II

Dispersion index (ID), statistic- $d$ and discrepancy index (D) for the parasites infracommunities of metazoan parasites of Hemibrycon surinamensis from the Matapi River, in Amapá State, Brazil.

\begin{tabular}{lcccc}
\hline \multicolumn{1}{c}{ Species of parasites } & ID & $\boldsymbol{d}$ & D & Dispersion type \\
\hline $\begin{array}{l}\text { Jainus hexops and } \\
\text { Tereancistrum ornatus }\end{array}$ & 1.464 & 1.53 & 0.564 & Random \\
Contracaecum sp. & 1.042 & 0.23 & 0.727 & Random \\
Clinostomus marginatum & 1.522 & 1.87 & 0.865 & Random \\
\hline
\end{tabular}

TABLE III

Component community of metazoan parasites of Hemibrycon surinamensis from the Matapi River, in Amapá State, Brazil.

\begin{tabular}{lc}
\hline \multicolumn{1}{c}{ Characteristics } & \\
\hline Number of examined hosts & 31 \\
Prevalence (\%) of parasites & 77.4 \\
Total number of parasites & 56 \\
Species of ectoparasites & 3 \\
Ectoparasites percentage & 50 \\
Ectoparasite (larvae) species & 1 \\
Species of endoparasites & 3 \\
Endoparasites percentage & 50 \\
Endoparasite (adults) species & 0 \\
Endoparasite (larvae) species & 3 \\
\hline
\end{tabular}

ornatus were lower than reported for this same host from the Igarapé Fortaleza basin (Hoshino et al. 2014). However, this is the first report of T. ornatus for $H$. surinamensis.

Current study on intermediate hosts of Contracaecum larvae in Brazil reported this endoparasite in 16 orders, 49 families, 140 species and 96 genera of fish (Pinheiro et al. 2019), demonstrating that this nematode have no host specifity, but present a broad geographic distribution. In the intestine of $H$. surinamensis, low levels of infection by larvae of Contracaecum sp. were found, as expected, because this omnivorous host also feed on microcrustaceans and mollusks (Hoshino et al. 2014, Froese and Pauly 2019) and is less likely to be infected compared to fish at the top of the food web (Hoshino et al. 2014). Infection levels by Contracaecum sp. were lower that reported by Hoshino et al. (2014) for H. surinamensis from the Igarapé Fortaleza basin. Contracaecum sp. are nematodes that at the adult phase preferentially infect piscivorous birds and fish, which may act as intermediate or paratenic hosts when they acquire these parasites by predation of other smaller fish or by predation of infected microcrustaceans (Vicente et al. 1995, Madi and Silva 2005, Torres et al. 2000, Pinheiro et al. 2019).

Metacercarie of Posthodiplostomum sp. were found in the intestine and swim bladder of $H$. surinamensis, while metacercariae of Clinostomus marginatum occurred in the gills and tegument, suggesting that this fish is an intermediate host for these digeneans. In addition, the presence of metacercariae of Posthodiplostomum sp. in the intestine of $H$. surinamensis indicates that it is possible that this host also feeds on other smaller fish, although they are not part of the its diet. Life cycle of the Posthodiplostomum species involves two intermediate hosts, a snail and a fish species, besides a definitive host, a piscivorous bird species (Ritossa et al. 2013). Clinostomum marginatum uses Biomphalaria species as an intermediate host and fish as secondary intermediate hosts, and its life cycle is completed in piscivorous birds, which are the definitive hosts (Pinto and Melo 2013, Pozza et al. 2018). Therefore, in populations of wild fish such as $H$. surinamensis, the transmission of these 
TABLE IV

Descriptors of diversity for parasites communities of metazoan parasites of Hemibrycon surinamensis from the Matapi River, in Amapá State, Brazil.

\begin{tabular}{ccc} 
Diversity indices & Mean \pm SD & Range \\
\hline Species richness & $1.1 \pm 0.8$ & $0-3$ \\
Brillouin index $(H B)$ & $0.2 \pm 0.3$ & $0-0.9$ \\
Evenness $(E)$ & $0.1 \pm 0.2$ & $0-0.7$ \\
\hline
\end{tabular}

digenean species occurs through the contact or ingestion of infected prey. Metacercariae may be more pathogenic to host fish than adult stages of digeneans (Kohn et al. 2013, Oliveira et al. 2017). Metacercariae of Clinostomum spp. can cause the yellow grub disease in freshwater fish (Pozza et al. 2018). In H. surinamensis, infection levels by metacercariae of these species of digeneans were lower than those reported for this same host in the Igarapé Fortaleza basin, which had the gills infected by Derogenidae metacercariae and Genarchella genachella (Hoshino et al. 2014). Such differences in infection levels are possibly related to differences in environments. Eutrophic environments such as the Igarapé Fortaleza basin favors the growth of ideal vegetation for the development of species of mollusks that are intermediate hosts of the digeneans (Pozza et al. 2018). This is the first report of Posthodiplostomum sp. and C. marginatum infecting $H$. surinamensis.

\section{CONCLUSIONS}

The community of metazoan parasites in $H$. surinamensis presented random dispersion, low species richness, low diversity and low evenness, and consisted of species with low prevalence, low abundance and dominance of ectoparasites. This omnivorous host occupies a low position in the food web, being consumed by other fish and piscivorous birds. This represent the third eco-epidemiological study for $H$. surinamensis.

\section{ACKNOWLEDGMENTS}

Ph.D. M. Tavares-Dias receives a Research Fellowship (\# 303013/2015-0) from the Conselho Nacional de Desenvolvimento Científico e Tecnológico (CNPq, Brazil).

\section{AUTHOR CONTRIBUTIONS}

Briani O. Sousa contributed with the data collection and text elaboration, Marcos S.B. Oliveira contributed with the fish and data collection and Marcos Tavares-Dias was the coordinator of this work.

\section{REFERENCES}

BAIA RRJ, FLORENTINO AC, SILVA LMAAND TAVARESDIAS M. 2018. Patterns of the parasite communities in a fish assemblage of a river in the Brazilian Amazon region. Acta Parasitol 63(2): 304-316.

BUSH AO, LAFFERTY KD, LOTZ JM AND SHOSTAK AW. 1997. Parasitology meets ecology on its own terms: Margolis et al. revisited. J Parasitol 83(4): 575-583.

CLOUTMAN DG. 1975. Parasite Community structure of largemouth bass, warmouth, and bluegill in Lake Fort Smith, Arkansas. Trans Amer Fish Soc 104(2): 277-283.

COHEN SC, JUSTO MCN AND KOHN A. 2013. South American Monogenoidea parasites of fishes, amphibians and reptiles. Rio de Janeiro: Oficina de Livros, 662 p.

EIRAS JC, TAKEMOTO RM AND PAVANELLI GC. 2006. Métodos de estudos e técnicas laboratoriais em parasitologia de peixes. Maringá: Eduem, 199 p.

FROESE R AND PAULY D. 2019. FishBase. World Wide Web electronic publication. Available at: www.fishbase.org. Accessed on February, 2019.

HOSHINO MDFG, HOSHINO EMAND TAVARES-DIAS M. 2014. First study on parasites of Hemibrycon surinamensis (Characidae), a host from the eastern Amazon region. Braz J Vet Parasitol 23(3): 343-347.

KOHN A, COHEN S, JUSTO MCN AND FERNANDES BMM. 2013. Digenea. In: Pavanelli GC, Takemoto RM and Eiras JC (Eds), Parasitologia: peixes de água doce do Brasil. p. 301-316.

KRITSKY DC AND LEIBY PD. 1972. Dactylogyridae (Monogenea) from the freshwater fish, Astyanax fasciatus (Cuvier), in Costa Rica, with descriptions of Jainus hexops sp. n., Urocleidoides costaricensis, and U. heteroancistrium combs, n. Proc Helm Soc Wash 39(2): 227-230. 
KRITSKY DC, THATCHER VE AND KAYTON RJ. 1980. Neotropical Monogenoidea. 3. Five new species from South America with the proposal of Tereancistrum gen. n. and Trinibaculum gen. n. (Dactylogyridae: Ancyrocephalinae). Acta Amaz 10(2): 411-417.

LUDWIG JA AND REYNOLDS JF. 1988. Statistical ecology: a primer on methods and computing. New York: WileyInterscience Pub., 337 p.

MADI RR AND SILVA MSR. 2005. Contracaecum Raillit e Henry, 1912 (Nematoda, Anisakidae): o parasitismo relacionado à biologia de três espécies de peixes piscívoros no reservatório do Jaguari, SP. Rev Brasil Zoocien 7(1): 15-24.

MAGURRAN AE. 2004. Measuring biological diversity. Oxford: Blackwell Science, 266 p.

MORAVEC F. 1998. Nematodes of freshwater fishes of the Neotropical region. Prague: Academia, 464 p.

OLIVEIRAMSB, GONÇALVES RA, NEVES LR, FERREIRA DO AND TAVARES-DIAS M. 2017. Ectoparasites community in Satanoperca jurupari (Cichlidae) from the Jari River, a tributary from Amazon River in Northern Brazil. Rev Bras Parasitol Vet 26(2): 136-142.

PINHEIRO RHS, FURTADO AP, SANTOS JN AND GIESE EG. 2019. Contracaecum larvae: morphological and morphometric retrospective analysis, biogeography and zoonotic risk in the amazon. Braz J Vet Parasitol 28(1): 12-32.

PINTO HA AND MELO AL. 2013. A checklist of cercariae (Trematoda: Digenea) in molluscs from Brazil. Zootaxa 3666(4): 449-475.

POZZA A, LIMA F, HAAS ML AND LEHMANNALBORNOZ PC. 2018. Clinostomum sp. (Digenea: Clinostomidae) and Ascocotyle sp. (Digenea: Heterophyidae): metacercariae with zoonotic potential in fishes from Tramandaí river basin, southern Brazil. Bol Inst Pesca 44(1): 105-109.

PRANG G. 2007. An industry analysis of the freshwater ornamental fishery with particular reference to the supply of Brazilian freshwater ornamentals to the UK market. Uakari 3(1): 7-51.

RITOSSA L, FLORES VR AND VIOZZI G. 2013. Life cycle of a Posthodiplostomum species (Digenea: Diplostomidae) in Patagonia, Argentina. J Parasitol 99: 777-780.

ROHDE K, HAYWARD C AND HEAP M. 1995. Aspects of the ecology of metazoan ectoparasites of marine fishes. Int J Parasitol 25(8): 945-970.

ROZSA L, REICZIGEL J AND MAJOROS G. 2000. Quantifying parasites in samples of hosts. J Parasitol 86(2): 228-232.

SILVA LMA, LIMA JF AND TAVARES-DIAS M. 2016. Ictiofauna como indicadora da qualidade ambiental do Rio Matapi, afluente do Rio Amazonas no Estado do Amapá (Brasil). Boletim de Pesquisa e Desenvolvimento, Embrapa Amapá, Macapá, 26 p.

TAKEMOTO RM, LUQUE JL, BELLAY S, LONGHINI CE AND GRAÇA RJ. 2013. Monogenea. In: Pavanelli GC, Takemoto RM and Eiras JC (Eds), Parasitologia: peixes de água doce do Brasil, p. 273-299.

TAKIYAMA LR, CUNHA AC, SILVA MS, MARTINS MHA, RODRIGUES LJC, AVELAR SB AND DIAS R. 2007. Subsídios à gestão de recursos hídricos na bacia hidrográfica do Rio Matapi. Macapá: IEPA. Relatório Técnico (Processo CNPq no 504083/2003-1).

THATCHER VE. 2006. Amazon fish parasites. $2^{\text {nd }}$ ed., Sofia: Pensoft Publishers, 509 p.

TORRES P, VALDIVIESO J, SCHALTTER R, MONTEFUSCO A, REVENGA J, MARÍN F, LAMILLA J AND RAMALTO G. 2000. Infection by Contracaecum rudolphii (Nematoda: Anisakidae) in the Neotropical cormorant Phalacrocorax brasilianus, and fishes from the estuary of the Valdivia river, Chile. Stud Neotrop Fauna \& Environm 35(2): 101-108.

VICENTE JJ, PINTO RM, NORONHAD AND GONÇALVES L. 1995. Nematode parasites of Brazilian Ciconiiformes birds: a general survey with new records for the species. Mem Inst Oswaldo Cruz 90(3): 389-393. 